\title{
脊椎発生動脈瘤様骨囊腫の治療経験
}

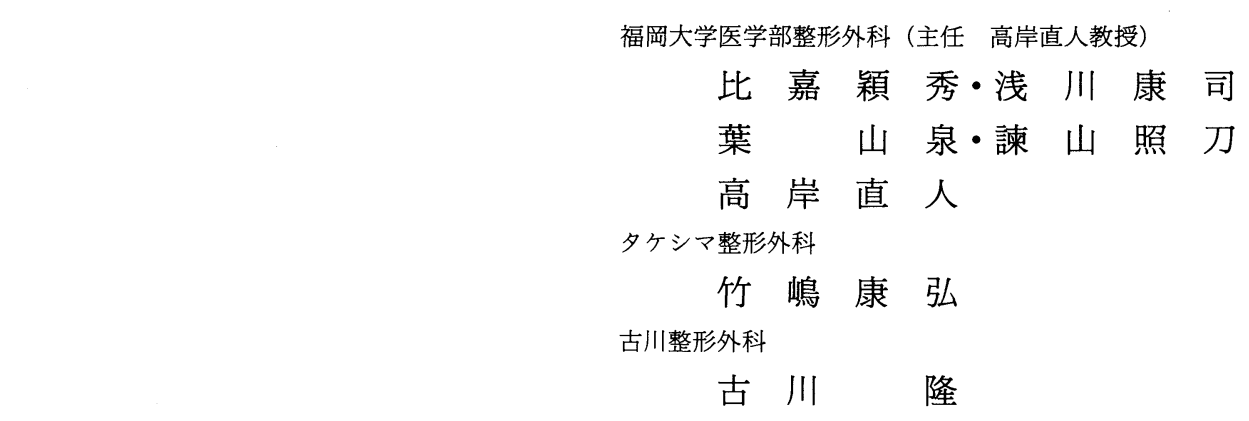

\section{Treatment for Aneurysmal Bone Cyst of the Second Lumbar Vertebra and Second Cervical Vertebra}

by

\author{
Eishuu Higa, Kouji Asakawa, Sansen Yoh, \\ Teruto Isayama and Naoto Takagishi \\ Department of Orthopedic Surgery, \\ Fukuoka University School of Medicine \\ Yasuhiro Takeshima \\ Takeshima Orthopedic Hospital \\ Takashi Furukawa \\ Furukawa Orthopedic Hospital
}

We presented two cases of aneurysmal bone cyst; one case in the second lumbar vertebra and the other case in the second cervical vertebra.

Case 1: a 15-year-old man

His chief complaint was low back pain. CT showed a expanded and destructive mass lesion from the transverse process to body of L2. After curettage of the lesion and bone grafting in the involved area of the vertebral body, a posteroeateral fusion was done. At 5 months following the operation, the patient had no recurrence showing a solid bony fusion on the roentgenograms.

Case 2: a 20-year-old woman

Her chief complaint was swelling of the posterior region of neck and severe pain referred to the left shoulder. Roentgenograms revealed a spherical tumor surrounded with a thin bone-shell. The tumor was resected and a left laminectomy of $\mathrm{C} 2$ was performed. Roentgenograms and CT showed no recurrence at 15 year after the operation. She was free of complaints.

\section{は じめに}

動脈瘤様骨囊腫 Aneurysmal bone cyst（以下 ABC と略す) は, 1942 年 Jaffe および Lichtensteinによっ て命名されて以来, 比較的まれな良性骨腫瘍として近
年症例報告が増加している.

最近われわれは第 2 腰椎に発生した $\mathrm{ABC}$ の手術例を 経験した.あわせて第 51 回西日本整災会で古川らが述 べた第 2 頸椎発生の術後 15 年の現在をここに報告し, 若干の文献的考察を加える. 
症

例

症例 $1: 15$ 歳, 男性.

主訴: 腰痛。

家族歴・既往歴：特記すべきものはない。

現病歴：昭和 63 年 8 月下旬, 友人に後ろからつかま えられ, 背中より転倒し腰痛出現。9月中旬より腰痛 が増強し, 昭和 63 年 9 月 17 日当科受診。 レ線上 $\mathrm{L}_{2}$ 右 椎弓根消失を認め, 第 2 腰椎骨腫晹疑いで, 昭和 63 年 10 月 4 日当科入院した。

入院時所見：体格中程度, 第 2 腰椎右側に自発痛, 圧痛を認めた。上, 下肢の運動, 反射は正常であった。 知賞は右大腿部前面に知覚鈍麻を認めた。膀胱直腸障 害は認められなかった。

血液生化学所見 : $\mathrm{ALP}_{3}$ の増加がみられた。

レ線所見 : 単純レ線上, 第 2 腰椎右椎弓根消失いわ ゆる pedicle sign および横突起の balloned out apearance を示した.また右腸腰筋消失を認めた (図 1 ).CT では, 第 2 腰椎の右横突起から体部にかけて骨破壊像 を認め，一部脊髄の压迫所見が見られた(図 2)。骨シ ンチにて, 第 2 腰椎右側に著明な集積がみられ, 他の 部位に異常集積はみられなかった。 MRIでは, 病変は 後方要素に発生しており，また多房性であることがわ かった(図 3 ).この他, 血管造影にて右第 2 腰動脈の 圧排があり, pooling を認める。腫湯濃染像は認められ ず,少なくとも hypervascularity ではなかった(図 4 ). また生検を行うと, 生検針より持続性の出血がみら

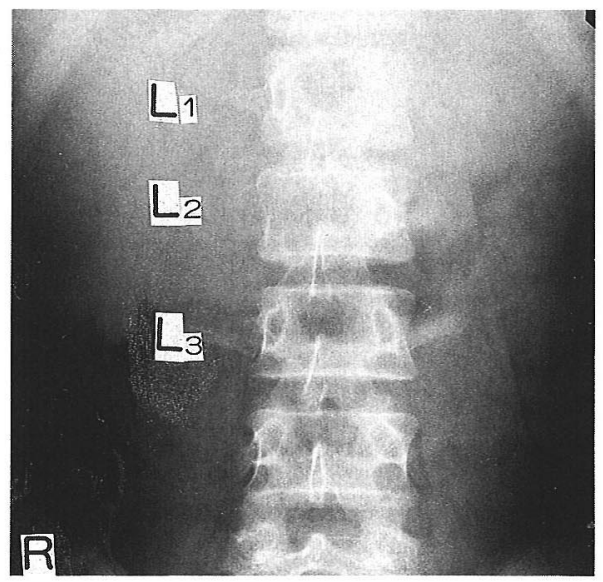

図 1 症例 $1 \quad \mathrm{~L}_{2}$ 右椎弓根消失と横突起膨隆を認め る.
れ，易出血性の腫瘍と思われた。その際の病理所見は ABCであった。

以上の所見より, 術前に embolization は行わず, 昭 和 63 年 10 月 24 日, 病巣搔爬, 骨移植, 後側方固定を 行った。

手術所見: $\mathrm{T}_{12}$ から $\mathrm{L}_{4}$ 棘突起に致る綐切開にて侵 入. 右側傍脊柱筋を外側によけると $\mathrm{L}_{2}$ 後方は, 椎弓か ら横突起にかけて紡錘形の膨隆が認められた。正常骨 組織は下関節突起と横突起に一部認められるのみで, 骨皮質は非薄化し骨内の暗赤色の腫湟組織が透見でき るほどで，硬度は弾性軟であった。 $\mathrm{L}_{1}$ 関節突起， $\mathrm{L}_{3}$ 上 関節突起の一部を削除し $\mathrm{L}_{2}$ の椎弓健常部を削除するこ とにより硬膜と $\mathrm{L}_{1}, \mathrm{~L}_{2}$ 神経根を露出した。腫瘍部分の 椎弓根部を切除することにより, 後方の腫瘍を一塊と して切除した。 $\mathrm{L}_{1}, \mathrm{~L}_{2}$ 神経根は腫瘤による軽度の圧迫 が確認された. 右椎弓根切除部より椎体後外側の腫瘍 を十分に搔爬し，腸骨採取骨を骨移植した。 $\mathrm{L}_{1}$ より $\mathrm{L}_{3}$ まで患側の後・側方固定，反対側の椎間関節固定を行

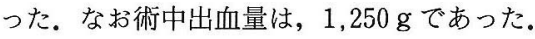

病理組織学的所見：大きな血管腔が多数みられ内部 に血液を含んでいる。血管周囲の線維性組織に多数の 巨細胞が認められ，一見巨細胞腫を思わせる像を呈し た。拡大をあげると，多核巨細胞であり核分裂像はみ られない。一部へモジデリン沈着を認めた（図 5 )。

術後経過：術後約 8 週ギプスベッド安静。その後, ギプスコルセット4 週し，さらに軟性コルセットを装 着した。術後 5 力月, レ線上再発なく骨疹合は良好で

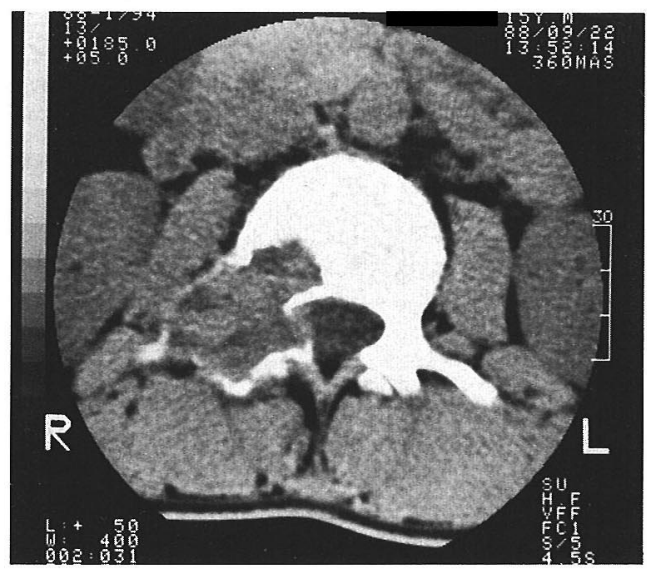

図 2 症例 1 CT 右横突起から体部にかけて骨破壊像を認める。 一部骨髄圧迫所見がみられる。 

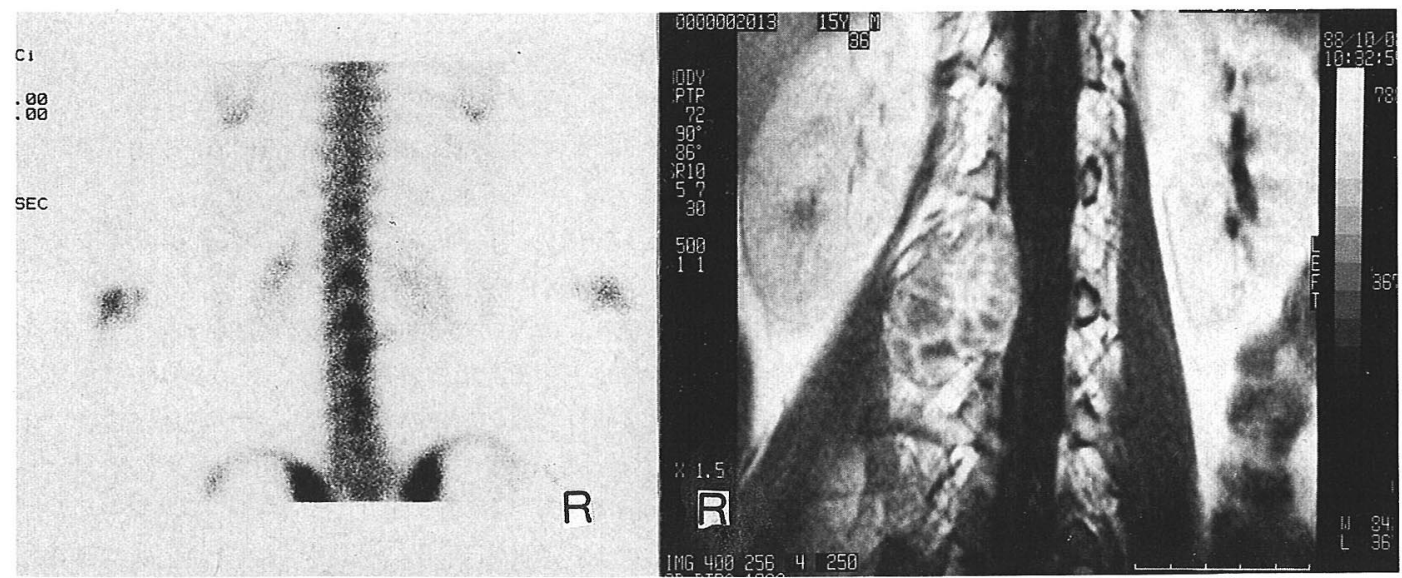

図 3 症例 1 骨シンチ

第 2 腰椎右側に著明な集積がみられる.他の部位に異常集積はみられない. MRI

病変は後方要素であり多房性像を示している.

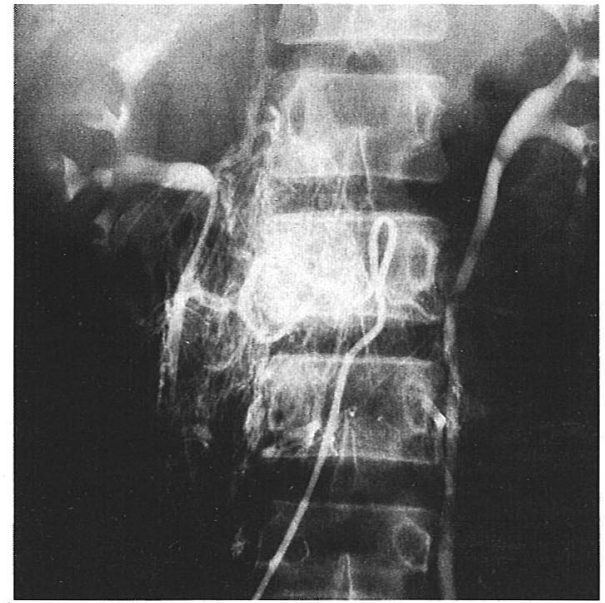

図 4 症例 1 血管造影

右第 2 腰動脈の圧排があり pooling を認める. 腫揚濃染像は認められない。

\section{ある(図 6)。}

症例 2 は第 51 回西日本整災において, 古川らが詳細 はその時述べている。

症例 $2: 20$ 歳, 女性.

主訴：頸部運動痛, 左側頚部から左肩の疼痛。

既往歷・家族歷：特記すべきものはない。

現病歴：昭和 48 年 11 月頃, 特に誘因なく上記主訴 が出現し近医受診。レ線上異常なく, 頸肩腕症候群で

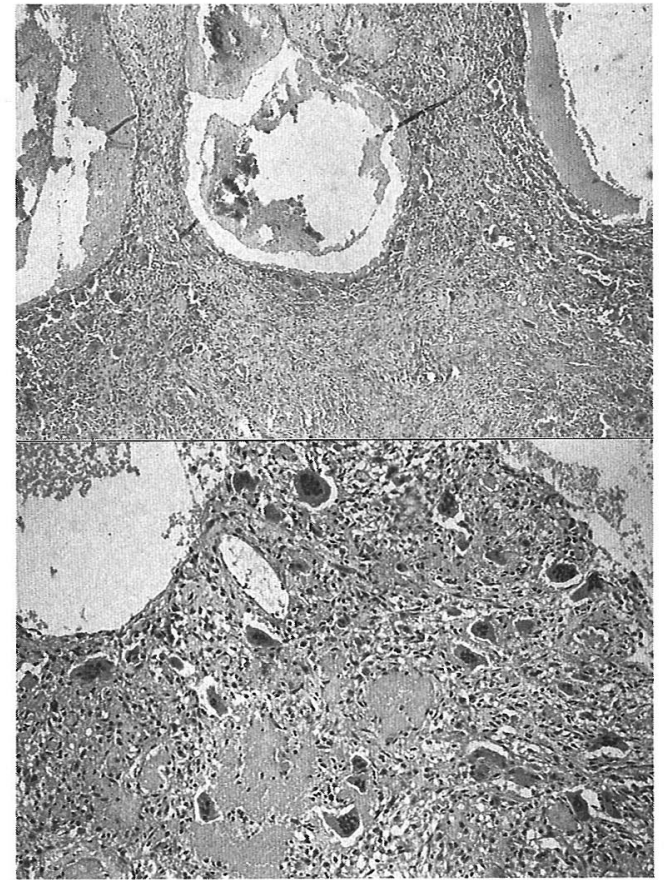

図 5 症例 1 大きな血管腔が多数みられ内部に血液 を含んでいる，血管周囲の線維性組織に多核巨 細胞がみられる。

保存的治療をうけた。初発より 5 力月後, 頸部の腫脹 出現, 頸椎の異常陰影を発見され当科紹介入院となる. 
入院時所見：頸部の運動制限，第 2 頸椎部の腫脹, 硬結を触れ圧痛がある。上，下肢の運動，反射，知覚 は正常. 病的反射はない。膀胱直腸障害はない.

レ線所見：単純レ線上, 第 2 䁰椎から第 3 頸椎の棘 突起より後方に囊腫様膨隆像いわゆる ballooned out apearance を示した. 断層撮影では，さらにはっきり した (図 7)。

以上の所見より第 2 頸椎の腫瘍を疑って, 腫瘍切除, 左椎弓切除を行った。

手術所見では腫瘍は棘突起部との固着はみられず, 第 2 頸椎の左椎弓後側と判断された。

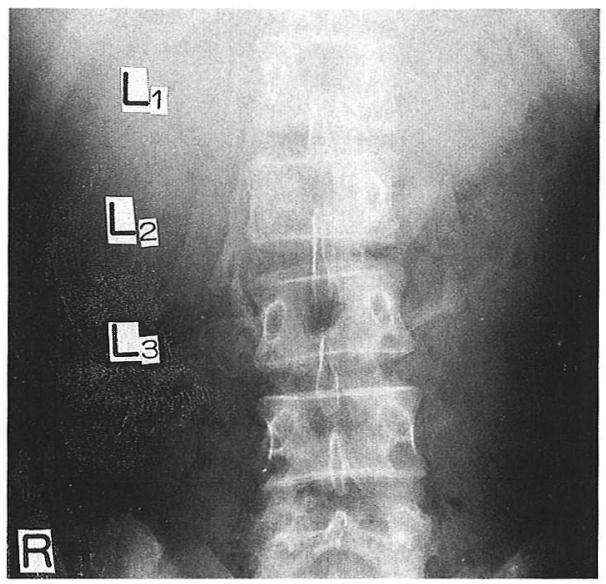

図 6 症例 1 術後 5 力月, レ線上再発なく骨㾍合は 良好である。

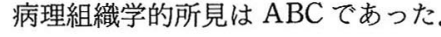

術後経過: 術後 1 週より頸椎カラー装着し術後 2 週 後除去した, 術後 15 年の現在, 何ら愁訴なく経過良好 で，第 2 頸椎，第 3 頸椎棘突起間が自然に骨瘾合して いる所見がみられる（図 8 ). CT 所見でも再発などの 所見はみられていない。

考察

動脈瘤様骨囊腫 Aneurysmal bone cyst は, 1942 年

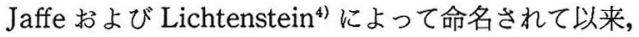
骨巨細胞腫, 孤立性骨囊腫などと異なる一つの独立疾 患として確立されている。しかしその本態に関しては 末だに不明である。

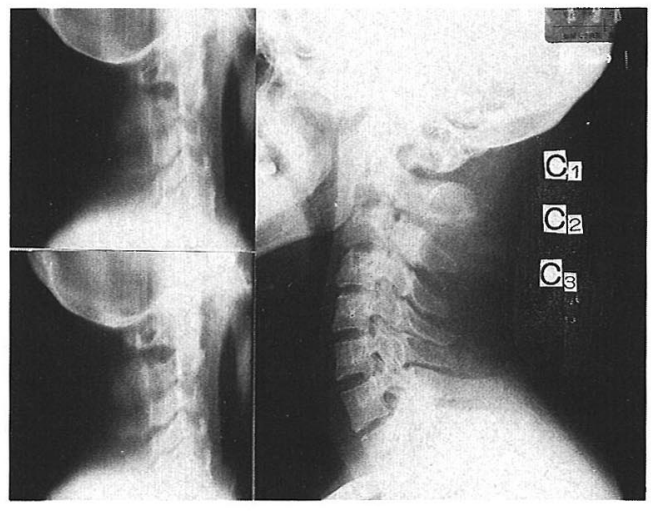

図 7 症例 2 第 2 頝椎から第 3 頝椎後方に襄腫様膨 隆像がみられる。

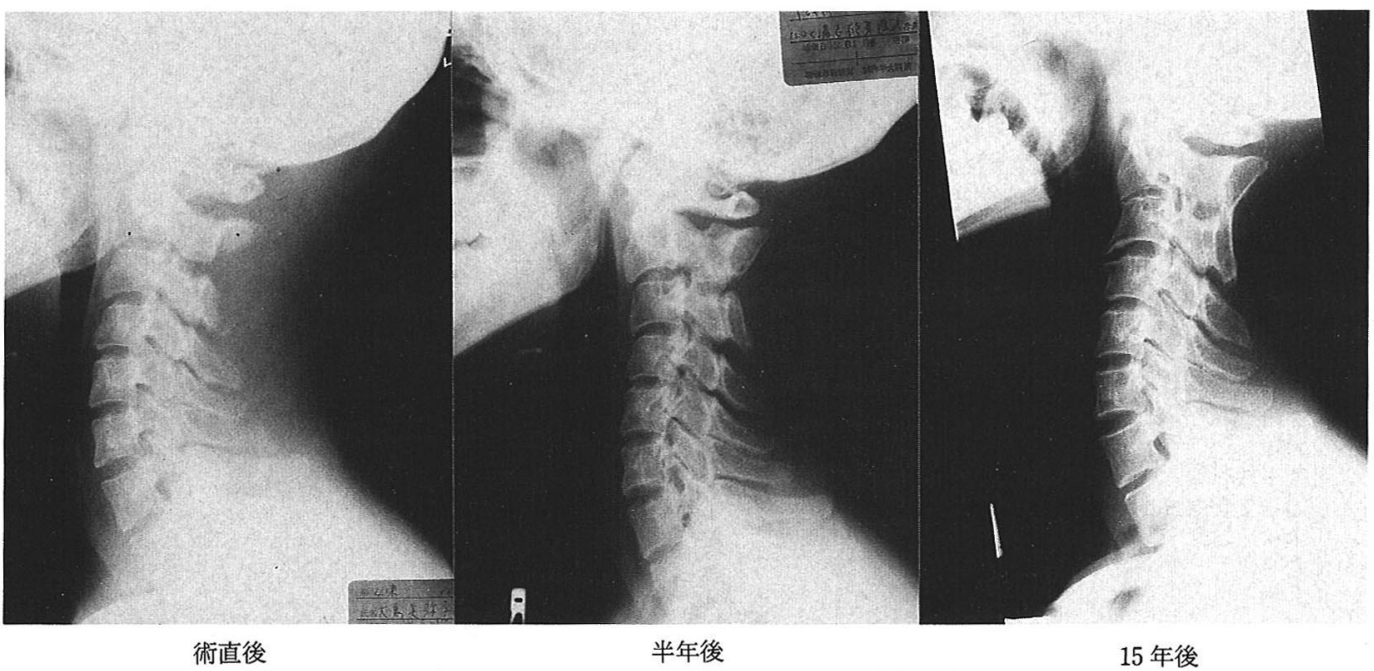

图 8 症例 2 術後 15 年の現在再発なく経過良好である。 
本邦の昭和 61 年度骨腫湟患者登録 ${ }^{11)}$ によると, 昭和 39 年から 61 年まで $\mathrm{ABC}$ は 379 名, そのうち脊椎発生 は 42 名である.さらに腰椎発生 15 名, 頸椎発生 9 名 である（表 1 , 表 2 ).

脊椎骨発生分布については, $\mathrm{Hay}^{6}$ によよると脊椎前方 要素に $40 \%$, 椎弓, 横突起などの後方要素に $60 \%$ 発生

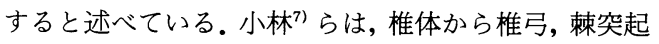
など後部脊椎にまたがるもの $42.5 \%$, 椎体のみ $15 \%$, 後部脊椎のみ $42.5 \%$ で後部脊椎に発生しやすいと述べ ている.われわれの 2 症例も同様で, 後部脊椎に発生 母地が求められた.

$\mathrm{ABC}$ の治療は一般に, 病巣搔爬・骨移植であり, 次 に放射線療法が行われている(表 3 )。ここで多数報告 例の文献を考察してみると, 杉浦 ${ }^{16)}(1982)$ は, 切除可 能な部位ならば病巣切除を行い, 切除不能ならば病巣 搔爬，骨移植を行う. 脊椎発生例では脊髄圧迫症状を みるときは, 除圧, 脊椎固定術が必要と述べている.

\section{表 $1 \mathrm{ABC}$ 脊椎発生頻度（全国骨腫崵患者登録表より）}

\begin{tabular}{cl|rll}
\hline \hline 頸 & 椎 & 9 & 例 & $(21.4 \%)$ \\
胸 & 椎 & 10 & $(23.8)$ \\
腰 & 椎 & 15 & $(35.7)$ \\
仙 & 椎 & 8 & $(19.1)$ \\
総 & 数 & 42 & $(100)$ \\
\hline
\end{tabular}

表 2 我国の腰椎発生例（文献報告例）

\begin{tabular}{|c|c|c|c|}
\hline 報告者 & 報告年 & 部位 & 治 \\
\hline 鈴 木 & 1968 & L 4 & 椎弓切除 \\
\hline 堀 & 1976 & L 3 & 摘出術 \\
\hline 鵜 飼 & 1977 & L 1 & 搔爬・骨移植, 固定, 照射 \\
\hline 山下 & 1980 & L 3 & 照射 \\
\hline 四方 & 1982 & L 3 & 搔爬・骨移植, 固定, 照射 \\
\hline 杉 浦 & 1982 & L 1 & 生検，照射 \\
\hline 宇都宮 & 1984 & L 5 & 搔爬・骨移植，固定 \\
\hline 藤 内 & 1986 & L 2 & embolization,搔爬 嗗移植, 固定 \\
\hline
\end{tabular}

表 $3 \mathrm{ABC}$ 治療法（全国骨腫瘍患者登録表より）

\begin{tabular}{l|rl}
\hline \hline \multicolumn{1}{c|}{ 治 療 法 } & 例 数 \\
\hline 手 術 & 325 例 \\
放射線 & 4 \\
手術+放射線 & 16 \\
手術十化学療法 & 2 \\
手術十放射線+化学療法 & 1 \\
治㾍ぜす & 22 \\
明 & 9 \\
\hline 総 数 & 379 \\
\hline
\end{tabular}

また骨盤, 春椎のように根治手術困難な部位, 巨大病 巣，完全搔爬できない病巣，再発病巣に対して放射線

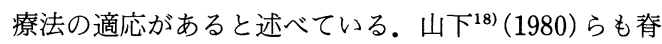
髄麻痺を合併する症例には病巣切除による除圧と脊柱 固定術の併用を述べている.藤内 ${ }^{3)}(1986)$ らは enblock resection が不可能な場合に病巣搔爬が行われるべき で，放射線治療は外科的治療の不可能な症例にのみ使 用されるべきであると述べている．梅田 ${ }^{17)}(1974)$ は進 行性の脊髄症状を伴うことの多い脊椎発生例は, 早期 根治治療が必要だと述べている。

脊椎発生例をみてみると, 病巣搔爬, 骨移植のみな らず,将来の変形予防として instrumentation の併用が 望ましいといわれているが,われわれの腰椎症例では, 2 度手術したくないという患者, 家族の希望があり instrumentation は行わなかった。

$\mathrm{ABC}$ の再発に関して Ruitar ${ }^{14)}$ (1975) らは ABCの 再発率は $30.5 \%$ と述べ, 搔爬術のみでは $34.2 \%$ 再発 すると述べている．また，Biesecker ${ }^{1)}$ (1970）らは搔 爬術で 59 \%再発したと報告している。搔爬術のみでは 再発率が非常に高いことを示しているが, Biesecker は, 一塊切除すれば再発はないと報告している. Clough ${ }^{2}$ （1973）も同様なことを述べている.

このように本疾患は再発例が散見されるが, 治療を 行えば, 比較的急速に症状が回復することが多いとい われる。また若年者ほど, 再発期間は短いともいわれ ている.

われわれの腰椎症例は術後 5 力月の現在, 再発なく 良好である. 今後も慎重に経過観察の予定である. 頸 椎症例は術後 15 年, 再発をみず, 何ら愁訴もなく経過 良好である。

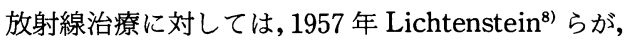
骨盤や脊椎など，外科的治療の困難な部位に対し放射 線治療の効果と有効線量を報告して以来, 放射線治療 の有効性が多数報告されている. Nobler ${ }^{12)}$ (1968) ら は積極的に放射線療法を勧めている.国内の報告では, 山下 (1980) らは脊柱発生の 4 例に最高 7,850 rad, 最 低 2,100 rad 照射し良好だったと述べ, 最適病巣線量は 2,000〜3,000 radだとまとめている. 杉浦（1982）ら は脊椎発生の 4 例に 2,000 3,000 rad 照射し, $3,000 \sim 4,000 \mathrm{rad}$ で病巣は脊椎外に限局性石兏化囊腫 を形成し安定化していく傾向をみると述べている．波 多野5) (1987) らは, 近年のX線の進歩に伴い, $500 \mathrm{rad,}$ $10 \mathrm{MV}$ という低線量高エネルギー照射を行い, 急速な 
病巣の縮小を認め, 1 年 6 カ月の現在, 再発をみてい ない 1 例を報告している。

一方, 放射線照射後の sarcoma ${ }^{9115)}$ の発生, Radiation Myelopathy ${ }^{1013)}$ といった放射線障害も報告され ており, 本質的に良性である本疾患に対しては, 慎重 な適応が望まれる。

以上の点をふまえ, 良性疾患ではあるが, 再発, 急 速な骨破壊といった性質を有する本疾患は, 杉浦も述 べているように, 発生部位, 大きさ, 破壊度, 神経症 状について慎重に検討し, また再発率の減少と機能温 存を考慮し，手術適応を決める必要がある.

\section{ま と め}

1）脊椎発生 $\mathrm{ABC}$ の腰椎, 頸椎の 2 手術例について 報告した.

2）一般に脊椎発生例は, 将来の変形予防として Instrumentation の併用が望ましいといわれるが,われ われの 2 症例では行わなかった。

3）本疾患は再発例が散見されるが，われわれの 2 例はともに再発がなく良好で, 特に頸椎症例は術後 15 年, 再発をみず, また何ら愁訴もなかった。

4）放射線治療は, 照射後の Sarcoma の発生, Radiation Myelopathy の発生も報告されており, 本質的に 良性である本疾患に対しては慎重な適応が望まれる.

5）良性疾患ではあるが再発，急速な骨破壊といっ た性質を有する本疾患は, 慎重に検討し手術適応を決 める必要がある。

\section{参 考 文 献}

1) Biesecker, J.L. et al.: Aneurysmal bone cyst, a clinicopathologic study of 66 cases. Cancer. $26: 615$ $-624,1970$.

2) Clough, J. R. et al. : Aneurysmal bone cyst ; Pathogenesis, and long term results of treatment. Clin. Orthop. $97:$ 52-63, 1973.

3）藤内 守 - 他: Aneurysmal bone cyst. 整形外科, 37 : 581-589, 1986.

4) Jaffe, H. L., Lichtenstein, L.: Solitary unicameral bone cyst, with emphasis on the roentgen picture, the pathologic appearance and the pathogenesis. Arch. Surg. 44 : 1004-1025, 1942.

5）波多野希・他：動脈瘤様骨囊腫に対する放射線治療の 1 例. 臨整外, $22 ： 1433-1437,1987$.

6) Hay, M. C. : Aneurysmal bone cyst of the spine. J. B. J. S. $60-$ B : 406-411, 1978.

7）小林健一・他：脊椎 Aneurysmal bone cyst $の 2$ 例.
中部整災誌，23：289-291，1980.

8) Lichtenstein, L. : Aneurysmal bone cyst, observations on fifty cases. J. Bone Joint Surg. 39-A : 873882, 1957.

9) Lichtenstein, L. : Aneurysmal bone cyst ; Further observation. Cancer. 6 : 1228-1237, 1953.

10）長瀬徹也・他：Radiation Myelopathyについて。臨 放, 19:451-462, 1974.

11）日本整形外科学会骨腫瘍委員会：全国骨腫瘍患登録 一覧表, 国立がんセンター, 東京, 1986.

12) Nobler, M. P. et al. : the cure of aneurysmal bone cyst. Radiology. 90 : 1185-1192, 1968.

13) Palmer, J. J. : Radiation myelopathy. Brain. 95 : 109-122, 1972.

14) Ruiter, D. J. et al. : Fibrinolytic activity in aneurysmal bone cysts. Am. J. Clin. Path. 64 : 810-816, 1975.

15) Sabanas, A. O. et al. : Postradiation sarcoma of bone. Cancer. 9 : 528-542, 1956.

16）杉浦 勲·他：動脈瘤様骨囊腫一病態と治療. 中部整 災誌, $25: 1492-1514,1982$.

17）梅田真一郎：頸椎に発生した Aneurysmal bone cyst の一治験例. 整形外科, $25: 820-823,1974$.

18）山下昌次・他：脊椎に発生した aneurysmal bone cyst の放射線治療. 臨床放射線, $25 ： 463-467,1980$.

\section{質 問国立福岡中央病院 篠原 典夫}

第 1 例の椎体外の腫瘍が bone shell を持っていたか, また組織学的に骨形成はみられなかったか.

\section{解 答 福岡大学 比嘉 頴秀}

bone shell は, X線でははっきりしないが, CT では そのような所見が認められた。

病理組織で，一部 Osteoid の形成がみられた。

\section{質 問大牟田私立病院 中島 雅典}

「第 1 例の MRI では動脈瘤様骨囊腫にみられる fluid-fluid levels は確認できますか？」

解 答福岡大学 比嘉 頴秀

fluid-fluid levels は認められなかった.

\section{解 答福岡大学 比嘉 頴秀}

症例 1 では $1,250 \mathrm{~g}$ であったが輸血は行っていない 症例 2 ではほとんど問題とならない程度の出血であ った. 